\title{
RESISTANCE OF AIRBORNE FUNGAL PROPAGULES TO ULTRAVIOLET IRRADIATION: LABORATORY STUDY
}

\author{
V. Ulevičius ${ }^{a}$, D. Pečiulytė ${ }^{\mathrm{b}}$, K. Plauškaitė ${ }^{\mathrm{a}}$, and N. Špirkauskaité ${ }^{\mathrm{a}}$ \\ a Institute of Physics, Savanoriu 231, LT-02300 Vilnius, Lithuania \\ E-mail: ulevicv@ktl.mii.lt \\ ${ }^{\mathrm{b}}$ Institute of Botany, Žaliuju ežeru 49, LT-08406 Vilnius, Lithuania
}

Received 30 July 2008; accepted 19 September 2008

\begin{abstract}
The influence of ultraviolet (UV) radiation on fungi Aspergillus niger Tiegh. isolate OG168, Paecilomyces puntonii (Vuill.) Nann. isolate OG68, and Penicillium expansum Link isolate PO88 was studied under laboratory conditions. A test system was developed for this study. An aerosol chamber provided a dust-free space of $1.5 \mathrm{~m}^{3}$. The source of ultraviolet rays was an UV lamp (DPT 220, 240-320 nm, $15 \mathrm{~W}$ ). Fungal propagules were injected into the UV exposed chamber space from an external bioaerosol generator. Aerosols from the aerosol chamber after irradiation to UV were sampled into an impinger AGI-30 and measured with the optical aerosol spectrometer LAS-15M (Institute of Physics, Lithuania). The changes in fungi survival caused by exposure to UV radiation were evaluated by determining their relative recovery. The laboratory study indicated that the fungal propagules responded to UV radiation distinctively. $P$. puntonii propagules were injured without possibility to repair. On the contrary, $P$. expansum propagules repaired after a long enough exposure to UV radiation, but this ability was limited. The stressed $A$. niger propagules recovered after the $80 \mathrm{~min}$ exposure to UV radiation and the relative recovery reached a plateau. The mutagenic effects of UV light on tested fungi have shown that frequent occurrence of different morphological mutants was detected after the $30 \mathrm{~min}$ exposure of conidia. The mean geometrical diameter of fungal propagules exposed to UV irradiation in the aerosol chamber was in the range of 2.5 to $2.8 \mu \mathrm{m}$.
\end{abstract}

Keywords: aerosol chamber, fungal propagules, relative recovery, mutation, UV radiation

PACS: 92.60.Mt, 92.20.Bk, 87.19.xg

\section{Introduction}

Thousands of microorganisms (fungi, bacteria, viruses, etc.) as one of components of ambient particulate matter constantly exist in the shape of aerosol particles in all size ranges and forms in outdoor and indoor air [1-5]. In recent years with an increase of the atmosphere pollution, attention of researchers to investigations of the survival of the microorganisms as objects inhabiting an increasingly changing polluted environment has raised $[1,6-8]$. Solar radiation, especially ultraviolet (UV) light, is a specific biophysical parameter playing an important role in the atmospheric microbial structure life $[6,7]$. The effects of the light are dependent on microorganism species $[1,6]$, their physiological state $[8,9]$, light intensity duration $[10,11]$, wavelength [10,12], etc.

As stratospheric ozone depletion progresses, more harmful solar UVB (i. e. 290-320 nm) radiation which is responsible for inactivation of microorganisms $[4,9]$ will penetrate the atmosphere to the Earth's surface and will induce variability of atmospheric microbial populations. Solar radiation appears to be a factor which could determine the atmospheric microbial structure and is limiting the upper boundary of the biosphere on the planet [3].

It is known that high doses of UV radiation are harmful to all living organisms in the following order: UVC $>$ UVB $>$ UVA. The ecological significance of UV radiation may be even greater than that of ionizing radiation in the environment. UV rays are absorbed by a substance whose maximum absorption is at a wavelength of 200-300 $\mathrm{nm}$. The main cellular target substance of UV for microbial death is known to be the DNR which has the maximum absorption at $265 \mathrm{~nm}$ [1]. In the case of UVC (below $290 \mathrm{~nm}$ ) and UVB radiation, the cause is a direct damage to nucleic acids and proteins that can lead to genetic mutation or cell death [8]. The mechanism of the UVA $(320-400 \mathrm{~nm})$ damage of cells is less understood, but it probably involves the generation of reactive oxygen molecules that can damage many different components 
of cells, including nucleic acids and proteins. Furthermore, low doses of UVA radiation can induce physiological responses in microorganisms, probably by activating specific genes [6]. The wide application of UVC radiation for disinfection of the indoor air and surfaces is also an important factor determining genetic variations of microorganisms. Many of the physiological and pathological effects of UVA radiation can be provoked by violet-blue light. This is most likely due to a common photochemical transduction process involving flavinoids and carotenoids. The mechanism associated with gene activation is unclear, and it is uncertain whether low doses of UVC and UVB radiation can induce similar responses. The percentage of the UVB is low ( $<1 \%$ of total energy) [9] but it has a highly active component of the solar spectrum which has the potential to cause wide-ranging effects, and it is assumed that shorter wavelengths have a major role in regulating both the size and the balance of atmospheric microbial populations $[3,6,10]$. UV light has been shown to be lethal and mutagenic in a variety of organisms, including plants $[13,14]$, bacteria $[4,5,15,16]$, yeast [17], and fungi $[11,12,18-20]$. There is a wide variety of microorganisms (germs) which cause contamination and vary in their structure and sensitivity to UV radiation. Airborne fungal propagules are highly adapted for survival because the air is their natural dispersal medium and they have various protective mechanisms. It is well documented that the main cellular target substance of UV for bacteria death is DNR and cell walls, in yeasts it is DNR, cell walls, and cell nuclei, and in fungi the main target is DNR, cell walls + pigments, and cell nuclei. Thus, fungal propagules dispersed in the air are less vulnerable to UV radiation damage.

Fungal propagules make up the main part of the microorganisms in the ambient aerosol particle $[1,6,12]$ and participate in processes occurring in other components, e.g. chemical. Therefore, changes in the cell processes, morphological structure, or in possible life cycle of the fungi recovered after UV radiation will be reflected in the chemical and physical composition of the aerosols and will directly influence the atmospheric processes. To our knowledge, only a few investigations on the effect of UV radiation on survival of fungi and bacteria in the air have been performed using aerosol technology [16,22]. Most of the investigations were performed by the method when a monolayer of fungal propagules on the static flat surface was irradiated $[2,7,8,11,20]$.

The aim of this study was the laboratory evaluation of the UV radiation induced changes in survivability of airborne fungal propagules by establishing conditions close to natural. The present study was carried out to assess the UV irradiation effect on aerosols of the fungal propagules, to compare resistance differences due to fungal morphology, to determine the lethality and the increase in mutation frequency.

\section{Materials and methods}

\subsection{Culture preparation}

When choosing fungi for the laboratory study, we took into consideration several criteria, i. e.: the fungal propagules must be most prevalent in the outdoor environment, easily aerosolized, able to grow fast on the laboratory media. The test fungi, Aspergillus niger Tiegh. (strain OG168), Paecilomyces puntonii (Vuill.) Nann. (strain OG68), and Penicillium expansum Link (strain PO88), were selected as representatives of species which are found in the ambient air and are known as microorganisms robust to environmental factors. Aspergillus and Penicillium are among the most common genera of fungi, isolated from the Lithuanian outdoor environment [21]. The fungi were incubated at $25^{\circ} \mathrm{C}$ and stored at $4{ }^{\circ} \mathrm{C}$ on the malt extract agar (MEA, Oxoid). P. expansum conidia are subglobose to ellipsoidal, with a physical diameter of 3.3-3.5 $\times$ 2.5-3.0 $\mu \mathrm{m}$, greenish, smooth-walled. A. niger conidia are globose to subglobose, $3.5-5 \mu \mathrm{m}$ in physical diameter, brown, ornamented with irregular warts, spines, and ridges. Fungus $P$. puntonii was selected because it has been reported as a causative agent of allergic alveolitis, humidifier disease, and as a sensitive microorganism [9]. P. puntonii was chosen as species of Paecilomyces genus with more stable morphology. Conidia of $P$. puntonii are ellipsoidal to cylindrical, with a physical diameter of 1.7-2.0 $\times 3.5-4.0 \mu \mathrm{m}$, smooth-walled.

The fungi were grown on MEA at $25^{\circ} \mathrm{C}$ for 14 days. Conidia of the 14-day culture of the fungi served as the material for irradiation. The suspensions of conidia filtered through cotton and sterile gauze in the ceramic filter were used in the experiment when they were irradiated as suspensions.

\subsection{The method of irradiation in the aerosol chamber}

The test system was developed to determine changes in survivability of airborne fungal propagules exposed to UV irradiation under conditions close to the outdoor environment and well-mixed air (Fig. 1). An aerosol chamber provided a dust-free space of $1.5 \mathrm{~m}^{3}$. The 


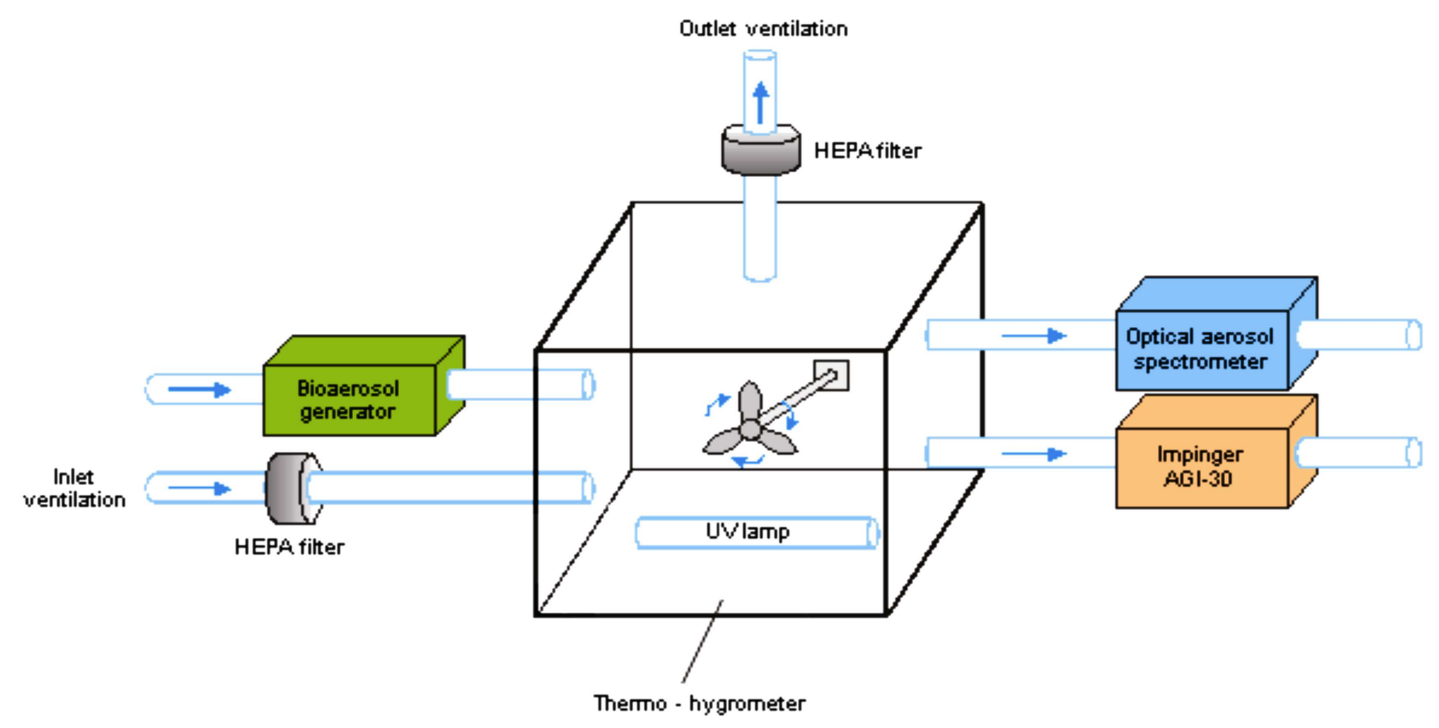

Fig. 1. Schematic representation of the experimental set-up.

chamber frame was made of strong aluminum tubes, which were covered with a double layer of the Teflon film. The two inlets of the chamber were sealed with HEPA filters. Air was pumped through the chamber providing an aerosol free space in the chamber. The top of the chamber was constructed so that it could be opened to place instruments inside the chamber. The bottom was covered with a plastic sheet wrapped into the Teflon film. An UV lamp (DPT 220, 240-320 nm, $15 \mathrm{~W}$ ), a fan, relative humidity and temperature sensors were mounted at the bottom of the chamber. A small opening in the aerosol chamber generated fungal propagules from an external bioaerosol generator into the UV exposed space. Other small openings were used to extract aerosols into an impinger AGI-30 and an optical aerosol spectrometer LAS-15M (Institute of Physics, Lithuania), and to supply power for the instruments inside the aerosol chamber.

The agar-tube disperser, one of the three bioaerosol generators developed at the University of Cincinnati (USA) [22, 23], was built for aerosolization of the fungal propagules. The external body of the disperser consisted of a cylindrical tube $(0.3 \mathrm{~m}$ long and $0.03 \mathrm{~m}$ inner diameter). Agar in a half-cylindrical container with microbial growth on it was placed inside the bioaerosol generator tube. The air flow was directed through the tube resulting in the release of propagules from the microbial growth. For this study one orifice was added at the entrance of the dispersion tube to increase the air turbulence in the tube and thus enhance the release of propagules. Test fungi were incubated on MEA in the half-cylindrical containers. A piece of fungus culture (14-days old) was transferred with an inoculating loop onto the medium surface trying to spread conidia on it. Inoculated containers were incubated for 7 days at $25^{\circ} \mathrm{C}$ in the dark. Fungal propagules were dispersed into UV exposed space of the aerosol chamber directly from the grown biomass.

Fungal propagules from the UV radiation space were collected into the impinger containing $20 \mathrm{ml}$ sterile quarter ringer solution. Sampling with the AGI-30 impinger was performed at the flow rate of $10 \mathrm{l} / \mathrm{m}$ for $5 \mathrm{~min}$ after every $15 \mathrm{~min}$ exposure to UV radiation. Samples were diluted in succession in the sterile quarter ringer solution and a viable count was performed in triplicate on MEA in plate media. The plates were incubated for 2,3 , and 7 days at $25^{\circ} \mathrm{C}$ in the dark prior to counting the number of colony-forming units (number of viable fungal propagules). When the UV dose was sufficiently high to ensure the $100 \%$ level of microbial inactivation, no colonies were observed on the MEA dishes. When the colonies were counted after 2, 3 , and 7 days, all the dishes were left for prolonged incubation and were counted again to ensure no bias due to microbial injury and further recovery.

The deposition velocity of fungal spores in the chamber was estimated using the methodology from [16]. The average deposition velocity was $0.06 \pm 0.03 \mathrm{~m} / \mathrm{h}$.

In parallel, the optical aerosol spectrometer was used for the determination of size distribution of fungal propagules and their total concentration. The relative recovery (\%) of fungi in aerosol samples removed from the aerosol chamber was estimated as a ratio of the number of colonies grown on MEA obtained with the impinger to the total number of the fungus propagules measured with the optical aerosol spectrometer. 


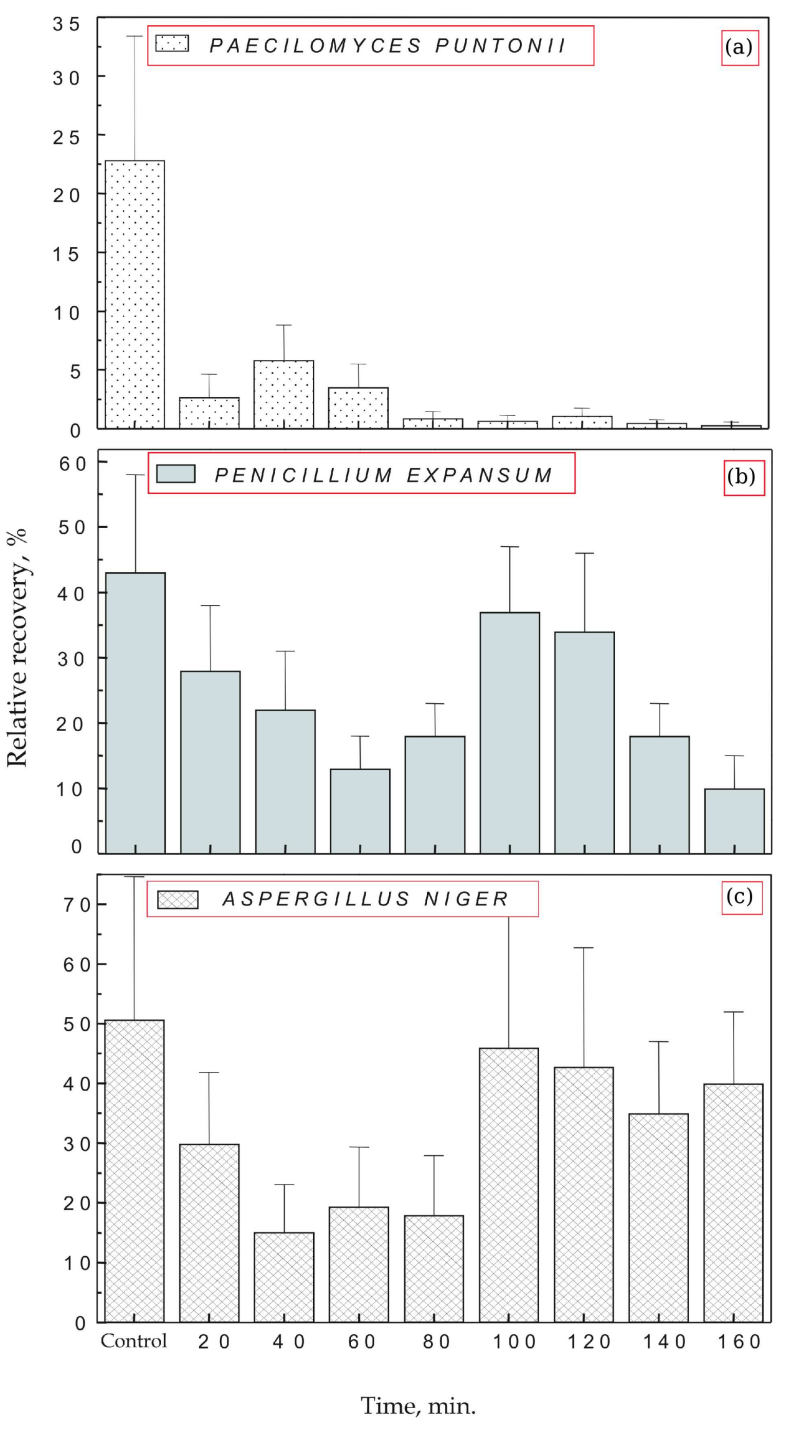

Fig. 2. Change in the relative recovery of fungal propagules during exposure to UV irradiation.

\section{Results}

Changes in survival of tested fungi caused by exposure to UV irradiation were evaluated by determining their relative recovery. Studies have shown that UV exposure induces a wide range of changes from fungal conidia death to many variations of temporary or permanent change to no change at all, due to isolate and exposure duration. The higher the given dosage (exposure time), the higher is the proportion of microorganisms destroyed. Fungal propagules exposed to UV irradiation in the aerosol chamber were at different physiological stages - viable or non-viable conidia or other colony forming units. For analysis of experimental data we followed a more operational definition of viability as "the ability of propagules to germinate and initiate vegetative or reproductive growth given proper envi-

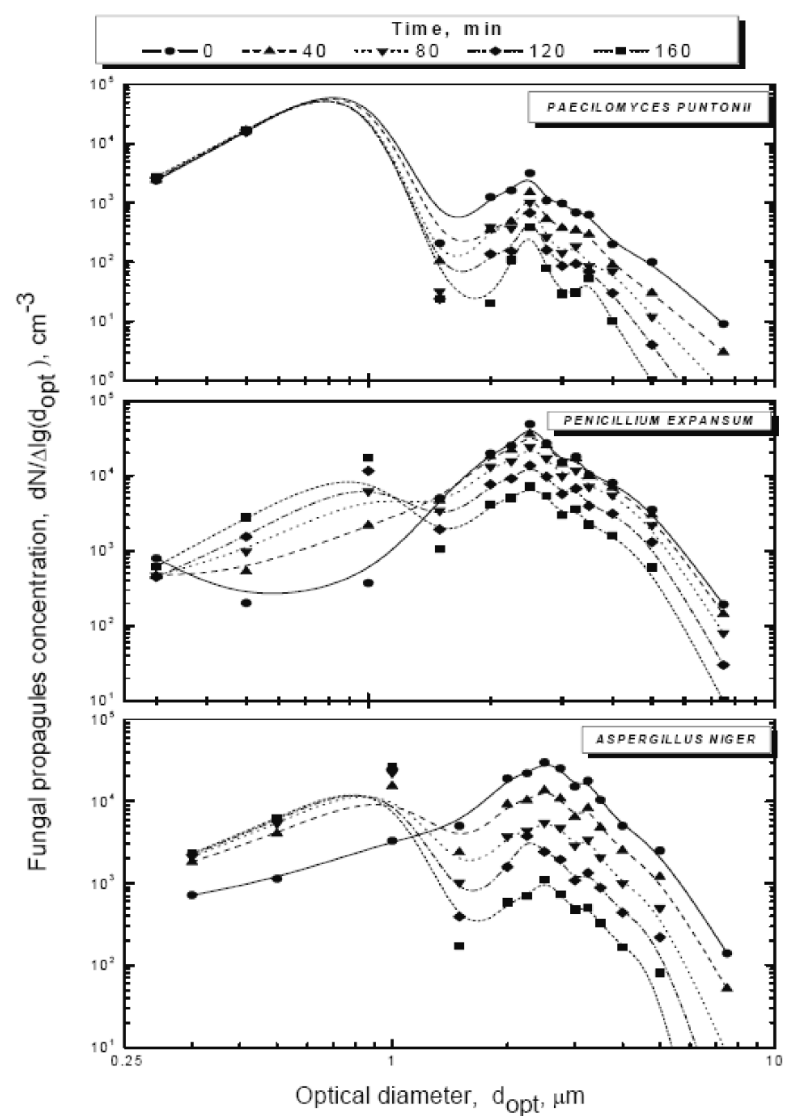

Fig. 3. Optical size distributions of fungal propagules exposed to UV irradiation.

ronmental conditions" by Campbell and Madden [24]. Germination may be interrupted for some time by UV irradiation, desiccation, or interruption of nutrition.

Viability of all three tested fungi decreased significantly with increased UV irradiation exposure. The relative recovery of fungi $P$. puntonii, $P$. expansum, and $A$. niger after different time of UV irradiation exposure is shown in Fig. 2. The initial relative recovery of fungus $P$. puntonii isolate OG68 (Fig. 2(a)) was only $22.8 \pm 10.6 \%$. This indicates that isolate was sensitive and fragment release was pronounced during the generation of fungus propagules. These fragments were in the same size range as live propagules and were counted with the optical particle spectrometer. Fungus propagules in the aerosol chamber were at different physiological stages - viable or non-viable conidia, hyphae fragments, or other units of fungus biomass. Conidia of tested fungi constituted up to $90-95 \%$ of the total number of fungal propagules in aerosol. A significant reduction of $P$. puntonii of the relative recovery occurred because of stress caused by UV irradiation. Most of $P$. puntonii conidia were injured after the 20 min exposure to UV radiation. They had no possibility to repair. This suggested that $P$. puntonii propagules had a lim- 
ited protection mechanism against UV radiation. It has been observed that after 30-40 min exposure the relative recovery was higher than after the 20 min exposure. P. puntonii propagules after the $60 \mathrm{~min}$ exposure to UV radiation as well as after the $20 \mathrm{~min}$ exposure had no possibility to repair. Only $1-3 \%$ of them formed colonies on MEA medium, and such low relative recovery level was also observed after the longer exposure (from 60 to 120 minutes) time.

Reaction of the fungi $A$. niger and $P$. expansum to UV radiation had their own distinctivenesses. As seen from Fig. 2(b), a significant decline in the relative recovery of $P$. expansum propagules lasted up to $60 \mathrm{~min}$ of the exposure to UV radiation. After $60 \mathrm{~min}$ exposure time the relative recovery started to increase and the percentage of recovered propagules started to grow up. These results have demonstrated that $P$. expansum propagules have ability to recover after being stressed. However, this ability is limited. The relative recovery dropped down after 120 min exposure to UV radiation. It appears that complicated processes occurred on pigmented walls of the conidia and inside the propagules. No mutations were induced by UV radiation in $P$. expansum population in the current investigation. Fungus $P$. expansum is known as a very common isolate in the outdoor and indoor environment, on various substrates, it can be resistant to the effect of various factors.

A. niger responded to UV radiation distinctively (Fig. 2(c)). First of all, initial relative recovery data did not indicate a significant release of fragments. Further recovery loss was significant up to $80 \mathrm{~min}$ exposure to UV radiation. After that the stressed fungal propagules recovered and the relative recovery reached a plateau of $\geq 35 \%$. This finding illustrates a high recovery potential of $A$. niger propagules and their ability to repair with time.

The optical size distribution of fungal propagules exposed to UV irradiation is shown in Fig. 3. The concentration of fungal propagules with the larger optical diameter was less than with $2.5 \mu \mathrm{m}$ due to deposition for all exposure times of UV irradiation. The aerodynamic diameter for fungal spores is typically $2.5-$ $3.0 \mu \mathrm{m}[22]$. The dependence of the concentration of fungal propagules on the exposure time was also observed: the longer the period of UV exposure, the lower concentration of fungal propagules was measured. This dependence could also be explained by deposition of fungal propagules. The concentration of $P$. puntonii was lowest compared to the other two fungal propagules. The concentration of $P$. expansum was highest and the concentration of A. niger depended on the UV expo- sure time more than concentrations of other two fungal propagules.

Besides the lethal effects, interesting secondary effects were observed in P. puntonii population after UV irradiation. A morphological divergence in fungus population was observed after UV irradiation and it was due to exposure time. Four phenotypes with different morphological characteristics were isolated from the cultures of irradiated conidia. The majority of them showed decreases in the pigment production and the growth rate. The morphological mutations - variations deviated from normal or wild-phenotype - were comparatively stable. Analysis of the culture obtained after UV irradiation showed a different degree of the population variability. The spectrum of morphological mutants induced by UV radiation and the frequency of their occurrence in the tested fungus population are presented in Table 1. No mutations appeared among 3000 control colonies grown from non-irradiated conidia. The colony growth and morphology changes were studied on the malt extract agar. The largest number of $P$. puntonii mutations was observed in the fungus population after 30 and 40 min exposure to UV irradiation. Longer UV radiation exposure (up to $120 \mathrm{~min}$ ) induced only a few mutant colonies among 3150 colonies grown on MEA. The frequency of the total variations deviated from normal (control - wild-type) in P. puntonii population after 30 min exposure to UV radiation was $1.0 \%$. Percentage distribution of the different mutants shows that mutant I dominated among the induced mutants making up 39\% of the total number. The concentration of mutant III was low but its morphological changes were conspicuous.

The colonial growth rate of mutant I and mutant II on MEA differed significantly from the control isolate (Fig. 4). The colonies of the P. puntonii conidia resistant to UV radiation were slightly smaller than those of non-irradiated conidia but these differences were not statistically significant. The growth rate of mutant III colonies was significantly different from the colonial growth of other mutants, but difference from the control colonial growth was insignificant.

Data obtained during the investigation of growth rates on different media suggested that ability to utilize various carbon sources was different and depended on the mutant type (Fig. 5). Most fungal propagules recovered after UV radiation - formed colonies which did not differ from control isolate (colonies formed from the non-irradiated propagules). However, their growth on some media such as Sabouraud peptone, Mycological peptone, Milk agar, and Czapek's agar was larger as 


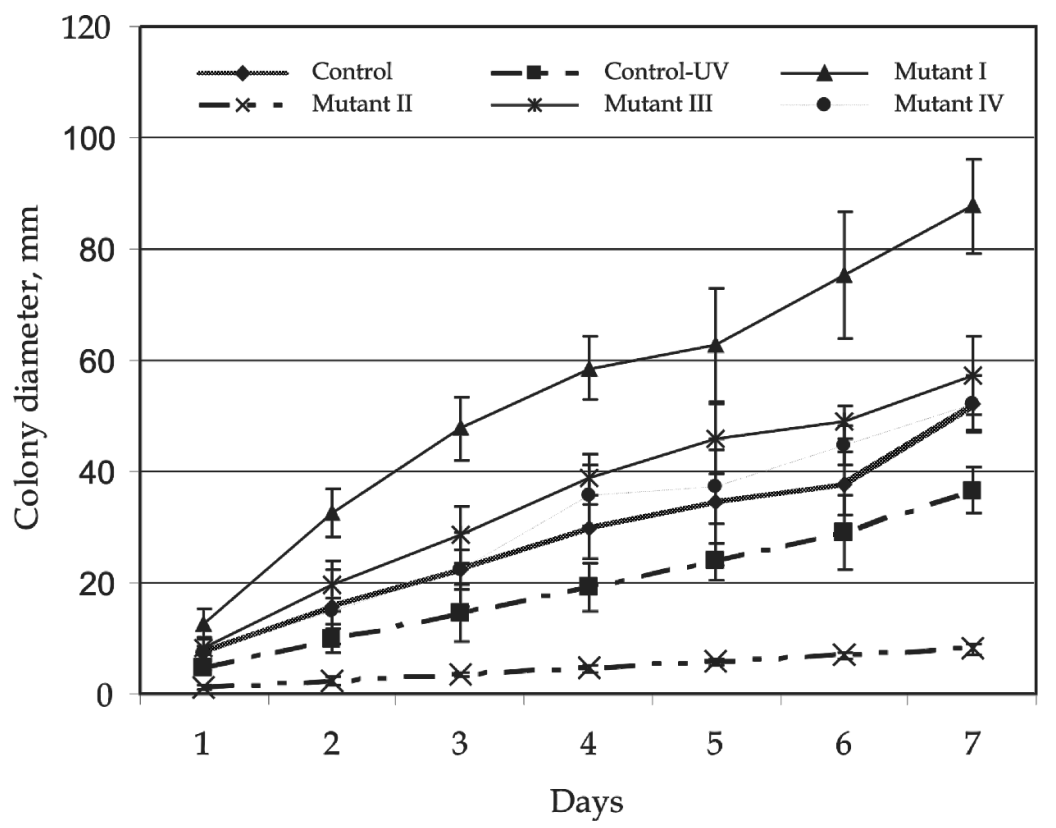

Fig. 4. Colony radial growth rate (evaluated as the colony diameter after 7 days of growth at $25^{\circ} \mathrm{C}$ on MEA) of P. puntonii and its mutants obtained after $30 \mathrm{~min}$ exposure to UV irradiation in the aerosol chamber.

Table 1. The morphological characteristics of the control isolate P. puntonii and UV-induced mutant strains grown on MEA at $25^{\circ} \mathrm{C}$ temperature in the dark.

\begin{tabular}{|c|c|c|c|c|c|c|}
\hline \multirow[b]{2}{*}{ Fungus } & \multirow{2}{*}{$\begin{array}{l}\text { Morphological } \\
\text { mutants } \\
\text { (\% of total } \\
\text { number) }\end{array}$} & \multirow{2}{*}{$\begin{array}{l}\text { Colony } \\
\text { grown } \\
\text { rate } \\
(\mathrm{mm} / \mathrm{h})\end{array}$} & \multirow{2}{*}{$\begin{array}{c}\text { Colony } \\
\text { diameter } \\
\text { after } \\
7 \text { days }(\mathrm{cm})\end{array}$} & \multicolumn{3}{|c|}{ Appearance of the colonies } \\
\hline & & & & Colour & Reverse & $\begin{array}{l}\text { Intensity } \\
\text { of } \\
\text { sporulation }\end{array}$ \\
\hline Wild isolate & - & $3.3-3.6$ & $5.5-6.0$ & Tan & $\begin{array}{c}\text { White to pale } \\
\text { yellowish }\end{array}$ & Abundant \\
\hline $\begin{array}{l}\text { Control isolate after } \\
\text { exposure to UV } \\
\text { irradiation (not mutated) }\end{array}$ & - & $2.7-3.0$ & $4.5-5.1$ & Tan & Yellow & Abundant \\
\hline Mutant I & 39 & $5.1-5.7$ & $8.5-9.5$ & White & Colourless & Limited \\
\hline Mutant II & 31 & $0.7-0.9$ & $1.2-1.5$ & Light-grey & Colourless & Absent or limited \\
\hline Mutant III & 6 & $3.9-4.3$ & $6.5-7.2$ & $\begin{array}{l}\text { Light-brown, sometimes } \\
\text { with white / brown } \\
\text { mycelium segments }\end{array}$ & Colourless & $\begin{array}{l}\text { Sparse but } \\
\text { less than in } \\
\text { control isolate }\end{array}$ \\
\hline Mutant IV & 24 & $2.6-3.0$ & $4.3-5.0$ & $\begin{array}{l}\text { Light-brown with } \\
\text { green shadows }\end{array}$ & Green & Abundant \\
\hline
\end{tabular}

compared with control isolate. UV radiation stimulated the growth rate of $P$. puntonii on these media. Mutant cultures had uniform morphology of colonies on all the growth media, but the growth rate differed depending on the medium composition.

Mutant I also utilized starch better than control isolate. The growth rate of mutant II was very low (from 0.027 to $0.181 \mathrm{~mm} / \mathrm{h}$ ) on all the investigated media (Fig. 5). Mutant III grew better on malt extract and malt extract + yeast extract medium than control iso- late. Mutant IV utilized all carbon substrates similarly as control isolate.

Each mutant type was studied in the period of 58 continuous generations. The populations of mutant I and mutant II were genetically stable - morphological changes did not revert to the control isolate. Mutant III and mutant IV were genetically unstable and reverted to control isolate after 5th or 4th passage, respectively. The population of mutant III after each new passage split into 3 types of colonies: subdivided colonies, 


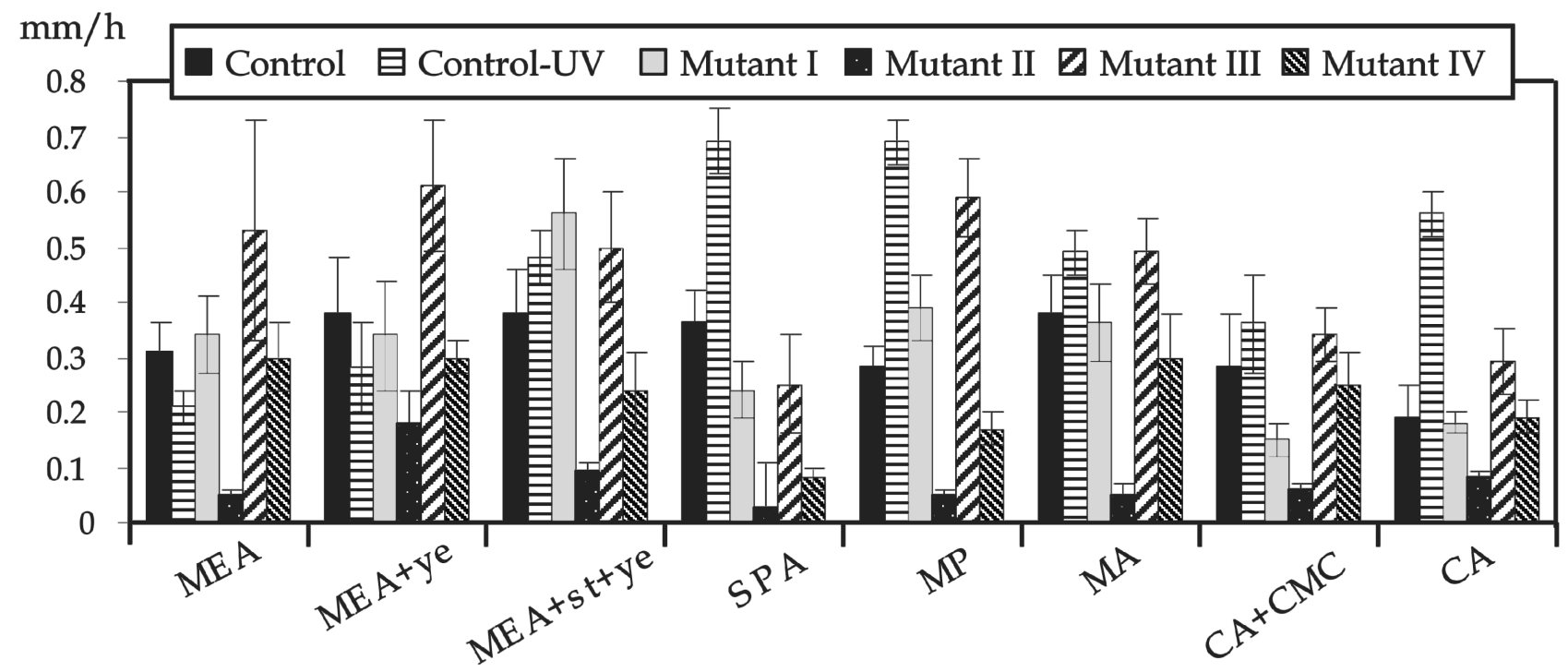

Fig. 5. Growth rate of $P$. puntonii control isolate, isolate after UV radiation and four mutants at $25^{\circ} \mathrm{C}$ on different media: malt extract agar (MEA), malt extract + yeast extract (MEA+ye), malt extract + starch + yeast extract (MEA +st + ye), Sabouraud peptone agar $($ SPA), mycological peptone (MP), milk agar (MA), Czapek's agar + carboxymethyl cellulose (CA+CMC), Czapek's agar (CA).

colonies consisting of very thin mycelium, and those with velvety appearance.

\section{Discussion and conclusions}

Irradiation of airborne organisms has been the primary focus of many studies, but only a few investigations have been performed on the recovery and physiological changes of microorganisms some time after UV radiation. The destruction of microorganisms by UV radiation is an exponential process. The higher the given dosage, the higher the proportion of destroyed microorganisms. Consequently, the dose necessary to destroy $99 \%$ of fungal propagules is double the value to destroy $90 \%$ of fungal propagules. It follows therefore that the dosage required to kill $99.9 \%$ is three times the value to destroy $90 \%$ and the dosage required to kill $99.99 \%$ is four times the value to destroy $90 \%$. Variations in ultra-violet light sensitivity can be due to the cell size, structure of cell wall or membrane, pigmentation, or the existence and capacity of repair systems.

Apart from the capacity for repair mechanisms, tolerance to UV radiation may be related to pigmentation, which for microorganisms is believed to play a protective function against injurious solar radiation [25]. For example, a cell wall is often pigmented with melanin, making the fungal propagules less vulnerable to UV radiation damage [26]. Mason et al. [27] suggested that in some organisms melanin may act as a biological electron exchange polymer. Due to this property and its free radical state, melanin has the ability to protect the cell against the reducing and oxidizing conditions, which might otherwise set reactive free radicals capable of disrupting metabolism. In many cases, it has been suggested that pigments in fungi are the main protective mechanisms against UV radiation [25, 28]. Therefore, exposure to UV radiation may not have a lethal effect on fungal propagules; however, it may cause changes in their metabolic activity. After deposition and growth, fungi may develop different forms, which are adapted for better survival under unfavourable conditions. This means that some of fungal species may become very resistant to mechanical, chemical, biological attack and may have significant influence on ecosystems.

The laboratory study of the survival of airborne fungal propagules exposed to UV irradiation in the aerosol chamber under conditions close to the outdoor environment has indicated that UV exposure induces a wide range of changes from fungal conidia death to many variations of temporary or permanent changes to no changes at all due to isolate and exposure duration. Investigations have shown that the growth rate of different mutant types depend on the chemical composition of media. The fungal propagules responded to UV radiation distinctively. P. puntonii propagules were injured without the possibility to repair. On the contrary, $P$. expansum propagules repaired after a long enough exposure to UV radiation. But this ability was limited. The stressed A. niger propagules recovered after $80 \mathrm{~min}$ exposure to UV radiation and the relative recovery reached a plateau. The mutagenic effects of UV light on tested fungi were quite frequent: occurrence 
of different morphological mutants was detected after 30 min exposure of conidia. The mean geometrical diameter of fungal propagules exposed to UV irradiation in the aerosol chamber was in the range of 2.5 to $2.8 \mu \mathrm{m}$.

\section{References}

[1] T. Yanagita, Natural Microbial Communities, Ecological and Physiological Features (Japan Scientific Societies Press, Tokyo and Springer Verlag, Berlin, 1990).

[2] J. Rotem, B. Wooding, and D.E. Aulor, The role of solar radiation, especially ultraviolet, in the mortality of fungal spores, Phytopathol. 75, 510-514 (1985).

[3] Y. Tong and B. Lighthart, Solar radiation has a lethal effect on natural populations of culturable outdoor atmospheric bacteria, Atmos. Environ. 31, 897-900 (1996).

[4] G.J. Herd, N.G. Muller, and J. Frick, Major role of Ultraviolet-B in controlling bacterioplankton growth in the surface layer of the ocean, Nature 361, 717-719 (1993).

[5] G. Ko, M.W. First, and H.A. Burge, Influence of relative humidity on particle size and UV sensitivity of Serratia marcescens and Mycobacterium bovis BCG aerosols, Tuber. Lung Dis. 80, 217-228 (2000).

[6] P.E. Hockberger, A history of ultraviolet photobiology for humans, animals and microorganisms, Photochem. Photobiol. 76, 561-579 (2002).

[7] E.C. Polard, S. Person, M. Rader, and D.J. Fluke, Relation of ultraviolet light mutagenesis to a radiationdamage inducible system in Escherichia coli, Radiat. Res. 72, 519-532 (1989).

[8] T. Schwarz, UV light affects cells membrane and cytoplasmic targets, J. Photochem. Photobiol. B 44, 91-96 (1998).

[9] R.P. Sinha, M. Klisch, A. Gröniger, and D.P. Häder, Mycosporine-like amino acids in the marine red alga Gracilaria cornea - effects of UV and heat, Environ. Exp. Bot. 43, 33-43 (2000).

[10] P.G. Ayres, T.S. Gunasekera, S. Rasanayagam, and N.D. Paul, Effects of UV-B radiation on foliar saprophytes and pathogens, in: Fungi and Environmental Change, eds. J.C. Frankland, N. Magan, G.M. Gadd (Cambridge University Press, Cambridge, 1996), pp. 32-50.

[11] D. Peciulyte and V. Ulevicius, Effect of ultraviolet irradiation on the germination, growth and variability of Paecilomyces puntonii (Vuill.) Nonnizzi, Biol. 3-4, 68-74 (2000).

[12] D. Peciulyte and V. Ulevicius, Fungal response to ultraviolet irradiation, Ecol. 3, 7-9 (1999).

[13] W. Bilger, T. Johnson, and U. Schreiber, UV-excited chlorophyll fluorescence as a tool for the assessment of UV-protection by the epidermis of plants, J. Exp. Bot. 52, 2007-2014 (2001).
[14] T.M. Robson, V.A. Pancotto, S.D. Flint, C.L. Ballaré, O.E. Sala, A.L. Scopel, and M.M. Caldwell, Six years of solar UV-B manipulations affected growth of Sphagnum and vascular plants in a Tierra del Fuego peatland, New Phytologist 160, 379-389 (2003).

[15] A. Muela, J.M. Garcia-Bringas, I.I. Arana, and I.I. Barcina, The effect of simulated solar radiation on escherichia coli: The relative roles of UV-B, UV-A, and photosynthetically active radiation, Microb. Ecol. 39, 65-71 (2000).

[16] J. Peccia, H.M. Werth, S. Miller, and M. Hernandez, Effects of relative humidity on the ultraviolet induced inactivation of airborne bacteria, Aerosol Sci. Technol. 35, 728-740 (2001).

[17] M.L. Smith and A.J. Fornacwe, p-53-mediater protective responses to UV irradiation, Proc. Natl. Acad. Sci. USA 94, 12255-12257 (1997).

[18] D.E. Aylor and S. Sanogo, Germinability of Venturia inaequalis conidia exposed to sunlight, Phytopathol. 87, 628-633 (1997).

[19] E. Levetin, R. Shaughnessy, C.A. Rogers, and R. Scheir. Effectiveness of germicidal UV radiation for reducing fungal contamination within airhandling units, Appl. Environ. Microbiol. 67, 37123715 (2001).

[20] J. Rotem and H.J. Aust, The effect of UV and solar radiation and temperature on survival of fungal propagules, J. Phytopathol. 133, 76-84 (1991).

[21] K.H. Domsch, W. Gams, and T.H. Anderson, Compendium of Soil Fungi (Academic Press, London, 1980).

[22] T. Reponen, K. Willeke, V. Ulevicius, S. Grinshpun, and J. Donnelly, Techniques for dispersion of microorganisms into air, Aerosol Sci. Technol. 27, 405-421 (1996).

[23] V. Ulevicius, K. Willeke, S. Grinshpun, J. Donnelly, X. Lin, and G. Mainelis, Aerosol generation by bubbling liquid: Characteristics and generator development, Aerosol Sci. Technol. 26, 175-190 (1996).

[24] C.L. Campbell and L.V. Madden, Introduction to Plant disease Epidemiology (John Wiley \& Sons, New York, 1990).

[25] C.M. Ignoffo and C. Garcia, Influence of conidial colour on inactivation of several entomogenous fungi by simulated sunlight, Environ. Entomol. 21, 913-917 (1992).

[26] N.N. Zhdanova and A.I. Vasilevskaja, Melanin Containing Fungi in the Extremal Conditions (Naukova Dumka, Kiev, 1988) [in Russian].

[27] H.S. Mason, H.E. Ingram, and B. Allen, The free radical property of melanins, Arch. Biochem. Biophys. 86, 230-255 (1960).

[28] A. Asthana and R.W. Tuveson, Effects of UV and phototoxins on selected fungal pathogens of citrus, Int. J. Plant Sci. 153, 442-452 (1992). 


\title{
MIKROMICETU AEROZOLIO ATSPARUMAS ULTRAVIOLETINEI SPINDULIUOTEI: KAMERINIAI TYRIMAI
}

\author{
V. Ulevičius ${ }^{\text {a }}$, D. Pečiulytė ${ }^{b}$, K. Plauškaite ${ }^{a}$, N. Špirkauskaitė ${ }^{a}$ \\ ${ }^{\text {a }}$ Fizikos institutas, Vilnius, Lietuva \\ ${ }^{\mathrm{b}}$ Botanikos institutas, Vilnius, Lietuva
}

\section{Santrauka}

Tirtas ultravioletinès (UV) spinduliuotès poveikis Aspergillus niger Tiegh (OG168), Paecilomyces puntonii (Vuill.) Nann. (OG68) ir Penicillium expansum Link (PO88) mikromicetu pradams, panaudojus aerozolio technologija. Tyrimai atlikti sukonstruotoje eksperimentineje $1,5 \mathrm{~m}^{3}$ aerozolio kameroje. Kamera buvo užpildoma mikromicetu pradais, generuojamais bioaerozolių generatoriumi. Jie buvo veikiami skirtingos trukmès (iki $160 \mathrm{~min}$ ) ultravioletine spinduliuote. Bandiniai iš kameros rinkti i sterilų vandeni kur 15 min intervalais optiniu aerozolio spektrometru LAS-15m (Fizikos institutas) matuota mikromicetu pradų koncentracija ir dydžiu pasiskirstymas. Mikromicetams auginti buvo naudota agarizuota alaus misa. Mikromicetai auginti 7 dienas tamsoje, $25^{\circ} \mathrm{C}$ temperatūroje. Mikromicetų pradų gyvybingumas buvo vertinamas pagal koncentracijų, išmatuotu aerozolio spektrometru vandens terpejje, santykị. Nustatyta, kad $P$. puntonii pradų pažaidos negrį̌tamos: dauguma jų žuvo paveikus UV spinduliuote $20 \mathrm{~min}$. P. expansum pradu gyvybingumas pradžioje sumažèjo, bet po 60 min poveikio UV spinduliuote pradèjo didèti, o po $120 \mathrm{~min}$ - vèl mažèti. Šiu mikromicetu pradų apsauginiai mechanizmai nuo UV spinduliuotès buvo riboti. Po $80 \mathrm{~min}$ UV spinduliuotès poveikio $A$. niger pradams jų gyvybingumas pradèjo didèti ir vèliau mažai kito. A. niger pradų apsauginiai mechanizmai nuo UV spinduliuotès buvo išvystyti geriausiai, lyginant juos su $P$. expansum ir $P$. puntonii. Daugiausia mikromicetu pradų mutaciju nustatyta paveikus UV spinduliuote $30 \mathrm{~min} P$. puntonii. Eksperimentinejje aerozolio kameroje veikiamu UV spinduliuote mikromicetu pradu vidutinis geometrinis skersmuo buvo nuo 2,2 iki $2,8 \mu \mathrm{m}$. 